\title{
Chemical compound isolated from antioxidant active extract of endophytic fungus Cladosporium tenuissimum in Swietenia mahagoni leaf stalks
}

\author{
FADHILLAH $^{1}$, ELFITA $^{2, \boldsymbol{\nu}}$, MUHARNI ${ }^{2}$, HENI YOHANDINI ${ }^{2}$, HARY WIDJAJANTI ${ }^{3}$ \\ ${ }^{1}$ Chemistry Graduate Program, Department of Chemistry, Faculty of Mathematics and Natural Sciences, Universitas Sriwijaya. Jl. Padang Selasa, \\ Palembang 30139, South Sumatra, Indonesia \\ ${ }^{2}$ Department of Chemistry, Faculty of Mathematics and Natural Sciences, Universitas Sriwijaya. J1. Raya Palembang-Prabumulih Km. 32, Inderalaya, \\ Ogan Ilir 30662, South Sumatra, Indonesia. Tel.: +62-711-580269, Fax.: +62-711-580269, "email: elfita69@ gmail.com, ila.fadhillah@ ymail.com \\ ${ }^{3}$ Department of Biology, Faculty of Mathematics and Natural Sciences, Universitas Sriwijaya. Jl. Raya Palembang-Prabumulih Km. 32, Inderalaya, Ogan \\ Ilir 30662, South Sumatra, Indonesia
}

Manuscript received: 7 July 2019. Revision accepted: 24 August 2019

\begin{abstract}
Fadhillah, Elfita, Muharni, Yohandini H, Widjajanti. 2019. Chemical compound isolated from antioxidant active extract of endophytic fungus Cladosporium tenuissimum in Swietenia mahagoni leaf stalks. Biodiversitas 20: 2645-2650. Swietenia mahagoni L. Jacq is a medicinal plant that widely used as an antimicrobial, anti-inflammatory, antimutagenic, anticancer, antitumor, and antidiabetic. Several bioactive compounds have been reported to be associated with this plant that supports its treatment activities. Flavonoid content of the $S$. mahagoni has antioxidant activity. Therefore the plant is widely used to treat degenerative diseases caused by free radical activity in the body. Scientists have proven that the medicinal plants have a symbiotic relationship with the number of microorganisms that can produce bioactive compounds. One of the symbiotic microorganisms is endophytic fungi believed to be associated with every plant on earth. In this paper, we report a secondary metabolite compound from endophytic fungi isolated from $S$. mahagoni. The endophytic fungi (DMG1-DMG4) were isolated from leaf stalks of S. mahagoni. Antioxidant activity of endophytic fungi extracts was tested by 2,2-diphenyl-1-picrylhydrazyl (DPPH) method. The chemical compound from the active extract was isolated by the chromatographic method, and the structure was elucidated by spectroscopic methods including UV, IR, NMR $1 \mathrm{D}\left({ }^{1} \mathrm{H}-\mathrm{NMR}\right.$ and ${ }^{13} \mathrm{C}-$ NMR), NMR 2D (HMQC and HMBC). Antioxidant activity test showed the endophytic fungus (DMG3) has the highest activity. The chemical compound from DMG3 was identified as 5-hydroxy-2-oxo-2H-piran-4-yl) methyl acetate). The phylogenetic method used to molecular analysis of DMG3 confirmed the fungus as Cladosporium tenuissimum.
\end{abstract}

Keywords: Antioxidant, Cladosporium tenuissimum, endophytic fungi, Swietenia mahagoni

\section{INTRODUCTION}

Free radical can cause cell damages in the human body. The use of the antioxidant compound can handle it as these can stop or retard free radical activity (Yadav et al. 2014). Free radicals have unpair electrons as an agent to disrupt healthy cells to an abnormal cell. Antioxidants donate their electron to free radical to become neutral molecules (Aguilar et al. 2016). There are two types of antioxidants, namely endogenous and exogenous. The antioxidant is a product of the body and obtained from outside the body through food intake (Ramayulis 2015). The body needs an exogenous antioxidant to increase its defenses from oxidative stress (Kasote et al. 2013). One type of plant that has been used by humans to treat diseases associated with free radical activity in the body is mahagoni (Swietenia mahagoni L. Jacq ). It has been widely used in many countries, including Asia, as a cure for various diseases. $S$. mahagoni has many beneficial effects on body health because it contains antimicrobial, anti-inflammatory, hepatoprotective, antioxidant, neuropharmacological, antiHIV, and immunomodulatory agents having pharmacological effects (Naveen et al. 2014). Biochemical compounds like flavonoids, quercetin, and isoflavones have been reported in several studies from extract biomass of $S$. mahagoni seed as a source of antioxidant (Bera et al. 2015; Syahwiranto and Theresi 2018). Biomass of $S$. mahagoni is easy to obtain as it was available throughout on the season, but excessive use of biomass may disrupt its the natural balance and can cause damage to its natural ecosystem. Besides this, S. mahagoni has a long growth period, and it can be harvested up to 10 to 15 years or more. Thus we need an alternative source to produce antioxidant compounds apart from biomass. In this study, we used extracts of liquid media of endophytic fungi from S. mahagoni.

Endophytic fungi are mutualistic symbiotic microorganisms living asymptomatically in the host plant tissue. These fungi have high ability to produce a variety of secondary metabolites depending upon their host plants and the environment around their host plants (Jalgaonwala et al. 2011; Ludwig-Muller 2015). The endophytic fungi live in the cell layer of the host plant without harming the host and have an essential role as a new source of bioactive compounds (Muharni et al. 2014; Deepthi et al. 2018). The literature of endophytic fungi from $S$. mahagoni is still minimal. Dompeipen et al. (2011) reported that the biomass of endophytic fungus from $S$. mahagoni rods has higher antioxidant activity when compared to biomass extract. 
Mutmainnah (2016) reported that endophytic fungi of $S$. mahagoni could be used as raw material to the medicine of diabetes mellitus, but the active compound of the product produced by endophytic fungi $S$. mahagoni has not been found.

\section{MATERIALS AND METHODS}

\section{Materials}

Leaf stalks of mahogany (Swietenia mahagoni) were obtained from Ogan Ilir, South Sumatra, Indonesia. The process of identifying plants was done in the Department of Biology, Sriwijaya University, Ogan Ilir District, South Sumatra Province, Indonesia.

\section{Sample sterilization and isolation of endophytic fungi}

Samples from leaf stalks of $S$. mahagoni was cleaned under running water. Alcohol $70 \%$ and $\mathrm{HgCl}_{2} 5 \%$ (w / v) were used to sterilize surface of sample for 1 minute. The samples were then rinsed with sterile distilled water. Furthermore, sterilized samples were inoculated in a petri dish containing PDA medium and incubate for 3-7 days at $37^{\circ} \mathrm{C}$ (Budiono et al. 2019). Fungi with different morphological features were separated and purified. Each colony was then transferred to a new PDA media with a streak plate method (Elfita et al. 2015).

\section{Cultivation and extraction of secondary metabolites of endophytic fungi}

Actively growing hyphae of endophytic fungi were inoculated in $300 \mathrm{ml}$ of media PDB (Potato Dextrose Broth) in the bottle and incubated at room temperature in static for six weeks. Endophytic fungi were inoculated into 30 bottles. The inoculation process was carried out in a sterile state with a PDB ratio of 1:10. After six weeks, the mycelium of Endophytic fungi and its culture media were separated and continued with partition by ethyl acetate (1:1). The extract was separated from medium and evaporated using a rotary evaporator at temperature $65^{\circ} \mathrm{C}$ to obtain concentrated ethyl acetate extract (Elfita et al. 2014).

\section{Antioxidant activity test with DPPH method}

The crude extracts of the endophytic fungi were diluted to 1000, 500, 250, 125 and $62.5 \mathrm{ppm}$. To each concentration, $0.2 \mathrm{~mL}$ was added to $3.8 \mathrm{~mL}$ DPPH $0.5 \mathrm{mM}$. The solution mixture was homogenized and left for 30 minutes in a dark place and absorption measured by UV-Vis spectrophotometer $(\lambda=517 \mathrm{~nm})$. Antioxidant activity was determined based on absorption inhibiting percentage of $\mathrm{DPPH}$ and $\mathrm{IC}_{50}$ value (Budiono et al. 2019).

$$
\% \text { Inhibition }=\frac{A b s(\text { Blank })-A b s(\text { Sample })}{A b s(\text { Blank })} \times 100 \%
$$

\section{Identification of endophytic fungi}

Isolates of endophytic fungi DMG3 was identified at the LIPI Cibinong biological research center. Internal transcribed spacer (ITS) of the ribosome DNA locus was used for identification. PHYTO nucleons pure reagent was used to extract DNA of isolated fungi DMG3. Primary ITS-4 and ITS-5 were used in PCR amplification (Liang et al. 2012; Pansanit and Pripdeevech 2018). The PCR amplicon was sequenced and blasted by using National Center for Biotechnology Information (NCBI) (Mishra et al. 2017). Fungal DNA with the highest similarity selected and grouped using ClustalW program (Hannula and Veen 2016) in txt, MSF, and PHYLIP formats (Felsenstein 1989). File PHYLIP opened with SEQBOOT program by entering 1000 times replication. DNAdist and Neighbor program run by entering the numbers 1000 as the amount of data processed. The last processed, the file was entered to CONSENSE program. Files names altered and added extensions, phb or tre. Figure phylogenetic tree created by TreeView (Puillandre et al. 2017) and edited by Mega4 program (Clifton et al. 2018).

Isolation and identification of pure compounds from the active ethyl acetate fraction of endophytic fungi extract

The concentrated extract was prepared and put into the chromatography column, then eluted with gradient solvent using n-hexane-ethyl acetate $(10: 0 \rightarrow 0: 10)$. Eluates were collected in vials $( \pm 10 \mathrm{~mL})$. The vials were detected by TLC then vials with the same stain pattern on the TLC were combined and concentrated with a rotary evaporator. The fraction that has a potential stain pattern was purified by chromatographic techniques and recrystallized to obtain pure compounds. The compound was determined by UV, IR, ${ }^{1} \mathrm{H}-\mathrm{NMR},{ }^{13} \mathrm{C}-\mathrm{NMR}$, HSCQ, and HMBC spectroscopy.

\section{RESULTS AND DISCUSSION}

\section{Sample sterilization and isolation of endophytic fungi}

Leaf stalk of $S$. mahagoni was sterilized by surface sterilization method. In this case, alcohol and $\mathrm{HgCl}_{2}$ were used as chemical sterilization agents. After the sample was incubated for 3-7 days, the growth of endophytic fungi began to appear. Four fungi had different physical characteristics labeled as DMG1-DMG4. Each fungus separated on different PDA medium.

\section{Cultivation and extraction of secondary metabolites of endophytic fungi}

The fungus growing on liquid PDB was harvested after an incubation period of 6 weeks by separating biomass from liquid media by filtration. The liquid media from the DMG1DMG4 fungus were extracted by partition method in ethyl acetate and the extracts were evaporated to obtain crude extracts DMG1= 4.37; DMG2 = 1.74; DMG3 = 5.98; and DMG4 $=2.21 \mathrm{~g}$, respectively.

\section{Antioxidant activity test with DPPH method}

The endophytic fungi extracts from leaf stalk of $S$. mahagoni have been evaluated of antioxidant activity by DPPH methods. The $\mathrm{IC}_{50}$ value of the extracts and ascorbic acid as standard antioxidant showed in Table 1 . The results of antioxidant activity test showed that DMG3 had the highest $\mathrm{IC}_{50}$ value compared to the others. Furthermore, the pure compound was isolated from fungus DMG3. 
Table 1. The $\mathrm{IC}_{50}$ value of endophytic fungi from ethyl acetate extract of $S$. mahagoni leaf stalks and ascorbic acid using DPPH method

\begin{tabular}{lll}
\hline Test samples & Extract & $\mathbf{I C}_{\mathbf{5 0}}(\boldsymbol{\mu g} \mathbf{g} \mathbf{m L})$ \\
\hline \multirow{3}{*}{ Endophytic fungi } & DMG1 & 2394.26 \\
& DMG2 & 1037.45 \\
& DMG3 & 85.35 \\
Ascorbic acid & DMG4 & 575.10 \\
\hline
\end{tabular}

\section{Identification of endophytic fungi}

Identification of DMG3 was carried out based on partial genetic analysis. DMG3 identified using the phylogenetic tree (Figure 2) by matching 1000 bootstrap. DMG3 fungi there was on the same clade as Cladosporium tenuissimum strain APBSDSF6 with high bootstrap support (99\%). It can be stated that DMG3 fungi is Cladosporium tenuissimum. The Counting of nucleotide bases from DMG3 fungi bellow:

TTAAGTTCAGCGGGTATCCCTACCTGATCCGAGGTCAAC CTTAGAAATGGGTTTGTTTTACGGCGTAGCCTCCCGAGC ACCCTTTAGCGAATAGTTTCCACAACGCTTAGGGGACAG AAGACCCAGCCGGTCGATTTGAGGCACGCGGCGGACCGC GTTGCCCAATACCAAGCGAGGCTTGAGTGGTGAAATGAC GCTCGAACAGGCATGCCCCCCGGAATACCAGGGGGCGCA ATGTGCGTTCAAAGATTCGATGATTCACTGAATTCTGCA ATTCACATTACTTATCGCATTTCGCTGCGTTCTTCATCG
ATGCCAGAACCAAGAGATCCGTTGTTAAAAGTTTTAATT TATTAATTAAGTTTACTCAGACTGCAAAGTTACGCAAGA GTTTGAAGTGTCCACCCGGAGCCCCCGCCCGAAGGCAGG GTCGCCCCGGAGGCAACAGAGTCGGACAACAAAGGGTTA TGAACATCCCGGTGGTTAGACCGGGGTCACTTGTAATGA TCCCTCCGCAGGTTCACCTACGGAGACCTTGTT .

Isolation and identification of pure compounds from the active ethyl acetate fraction of endophytic fungi extract

The concentrated extract of DMG3 was tested for stain pattern with TLC. Ratio solvent used on TLC is n-hexane: ethyl acetate $(10: 0 \sim 0: 10)$. The extract was separated over silica gel (230-400 mesh) by vacuum liquid chromatography method using gradient solvent n-hexane: ethyl acetate (10: 0 $\rightarrow 0$ : 10). Eluates were monitored using TLC to obtain four fractions $\left(F_{1}-F_{4}\right)$. The potential fraction $F_{3}$ was separated using a gravity column chromatography to obtain 57 vials. Each vial was analyzed for the stain patterns with TLC and obtained five fractions $\left(\mathrm{F}_{3.1}-\mathrm{F}_{3.5}\right)$. Furthermore, the fraction $\mathrm{F}_{3.5}$ separated by column chromatography using eluent nhexane: ethyl acetate (2: 8). The vial 7 as white crystal was examined using TLC and showed a single stain which fluorescent at the UV lamp. The pure compound was identified by spectroscopy method. The ${ }^{1} \mathrm{H}-\mathrm{NMR}$ spectra showed the presence of four signal proton. The ${ }^{13} \mathrm{C}-\mathrm{NMR}$ spectra appeared the signal at eight chemical shift for eight carbon (Fig 1). The correlation between protons and carbon showed in HMQC and HSQC spectra (Figure 1 and Table 2).

A

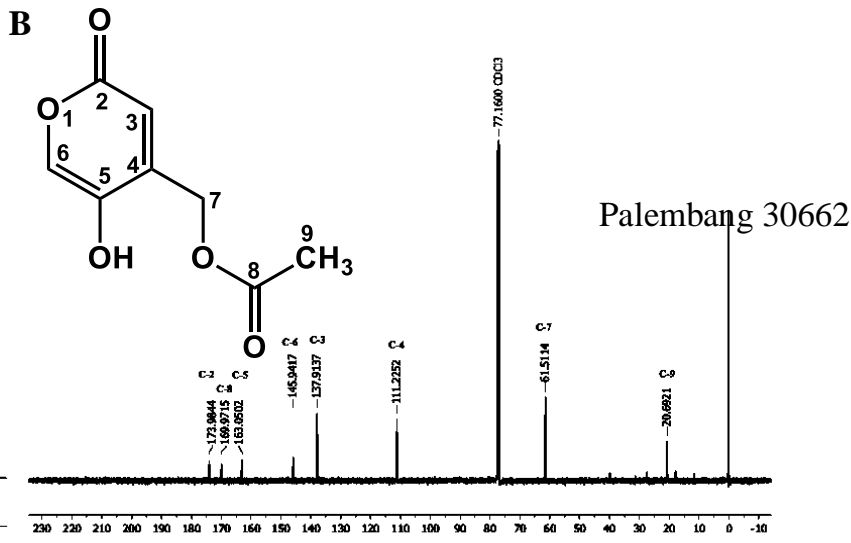

C

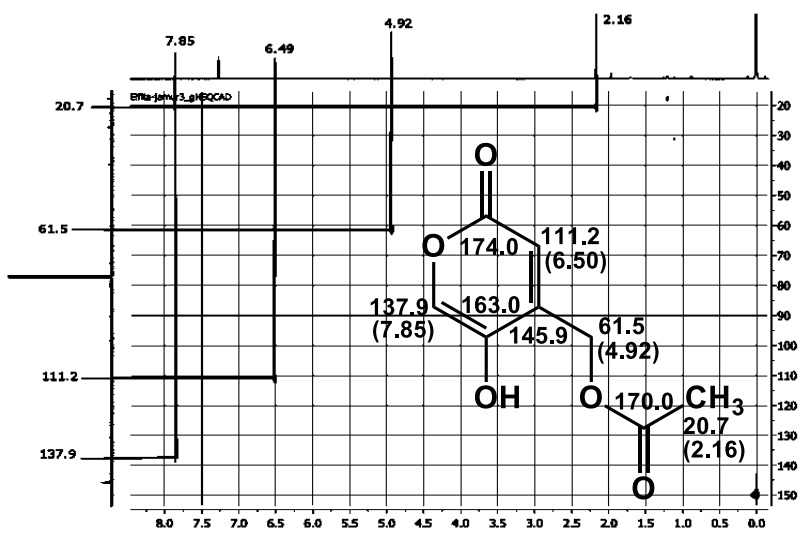

D

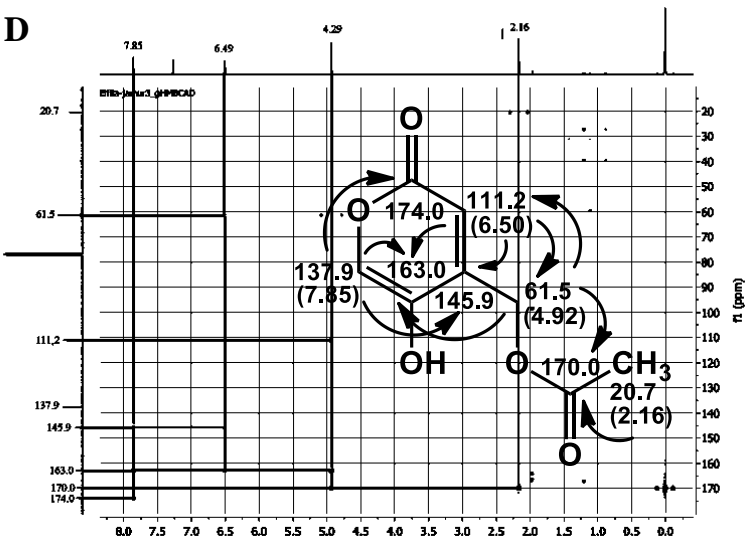

Figure 1. The ${ }^{1} \mathrm{H}-\mathrm{NMR}(\mathrm{A}),{ }^{13} \mathrm{C}-\mathrm{NMR}(\mathrm{B})$, HSQC (C), and $\mathrm{HMBC}(\mathrm{D})$ spectra of compound $\mathbf{1}\left({ }^{1} \mathrm{H}-500 \mathrm{MHz},{ }^{13} \mathrm{C}-125 \mathrm{MHz}\right.$, in CDCl $)$ 
Table 2. ${ }^{13} \mathrm{C}$ and ${ }^{1} \mathrm{H}$ NMR of compound $1\left({ }^{1} \mathrm{H}-500 \mathrm{MHz},{ }^{13} \mathrm{C}-125 \mathrm{MHz}\right.$, in $\left.\mathrm{CDCl}_{3}\right)$ and 5-hydroxy-2-oxo-2H-Piran-4-yl) methyl acetate $\left({ }^{1} \mathrm{H}-500 \mathrm{MHz},{ }^{13} \mathrm{C}-125 \mathrm{MHz}\right.$, in $\left.\mathrm{CDCl}_{3}\right)$ (Elfita et al. 2014)

\begin{tabular}{|c|c|c|c|c|c|c|}
\hline \multirow[b]{2}{*}{ No. $\mathrm{C}$} & \multicolumn{2}{|l|}{$\delta_{\mathbf{C}}(\mathbf{p p m})$} & \multicolumn{2}{|c|}{$\delta_{\mathbf{H}}(\mathbf{p p m}), \sum \mathbf{H}$, multiplicity } & \multicolumn{2}{|c|}{ HMBC } \\
\hline & $\begin{array}{c}\text { 5-hydroxy-2-oxo-2H- } \\
\text { Piran-4-yl) methyl } \\
\text { acetate }(*)\end{array}$ & Compound 1 & $\begin{array}{c}\text { 5-hydroxy-2-oxo-2H- } \\
\text { Piran-4-yl) methyl } \\
\text { acetate }(*) \\
\end{array}$ & $\begin{array}{c}\text { Compound } \\
1\end{array}$ & $\begin{array}{c}\text { 5-hydroxy-2-oxo-2H- } \\
\text { Piran-4-yl) methyl } \\
\text { acetate (+) } \\
\end{array}$ & Compound 1 \\
\hline 2 & 173.9 & 174.0 & & & & \\
\hline 3 & 111.2 & 111.2 & $6.50(\mathrm{H} ; \mathrm{s})$ & $6.50(\mathrm{H} ; \mathrm{s})$ & $145.8 ; 162.9$ & $61.5 ; 145.9 ; 163.0$ \\
\hline 4 & 145.8 & 145.9 & & & & \\
\hline 5 & 162.9 & 163.0 & & & & \\
\hline 6 & 137.9 & 137.9 & $7.85(\mathrm{H} ; \mathrm{s})$ & $7.85(\mathrm{H} ; \mathrm{s})$ & $145.8 ; 162.9 ; 173.9$ & $145.9 ; 163.0 ; 174.0$ \\
\hline 7 & 61.4 & 61.5 & $4.90(2 \mathrm{H} ; \mathrm{s})$ & $4.92(2 \mathrm{H} ; \mathrm{s})$ & $111.2 ; 162.9 ; 169.8$ & $111.2 ; 163.0 ; 170.0$ \\
\hline 8 & 169.8 & 170.0 & & & & \\
\hline 9 & 20.6 & 20.7 & $2.15(3 \mathrm{H} ; \mathrm{s})$ & $2.16(3 \mathrm{H} ; \mathrm{s})$ & 169.8 & 170.0 \\
\hline
\end{tabular}

Note: *) Elfita et al. (2014)

\section{Discussion}

Sample sterilization and isolation of endophytic fungi

There are many microorganisms in one type of plant. Therefore, it needs methods to isolate endophytic fungi associated with plants. Several techniques were needed to get pure endophytic fungi. The first thing to do to isolating endophytic fungi was to wash fresh S. mahagoni leaf. Samples washed with running water to remove impurities on the leaf surface and sterilized by surface sterilization method. It aims to remove epiphytic fungi and other microorganisms from the surface of plant tissues. Chemical sterilization in this was carried out by the use of alcohol $70 \%$ and $\mathrm{HgCl}_{2}$. The utilization of alcohol intends to remove fungi and bacteria found on the surface of the leaf stalk of $S$. Mahagoni. Whereas $\mathrm{HgCl}_{2}$ was used to maximize the sterilization process. $\mathrm{HgCl}_{2}$ can remove microorganisms by inhibiting enzyme activity can cause protein precipitation. Its impact on damage cell triggers the death of microorganisms (Hyde and Soytong 2008; Fouda et al. 2015). In this isolation process, the PDA medium was used to grow the fungus because it has simple formulation, and that can support the growth of various fungi (Akharaiyi and Abiola 2016).

\section{Cultivation and extraction of secondary metabolites of endophytic fungi}

DMG1-DMG4 fractions were cultivated in slanted medium to multiply the fungi that have isolated. A homogenous suspension of the fungi was grown in distilled water. The fungus suspension inoculated into liquid media PDB made from potato powder and dextrose, which is a food source for fungi and yeast and used to grow and identify fungi (Pradeep et al. 2013). Furthermore, fungus culture incubated for six weeks. The fungi were harvested with filtering the medium to separating from its biomass. Liquid medium extracted by ethyl acetate. The extraction was aimed to separate a substance that was contained in the sample. That is based on differences in solubility and level of the polarity of the solvent to get bioactive compounds in the sample (Altemimi et al. 2017). The extraction was also carried out to attract antioxidant compounds. It was contained in extracts of endophytic fungal liquid medium
DMG1-DMG4. The ethyl acetate is a semi-polar solvent. The generally semi-polar solvent like phenol and flavonoid derivatives has antioxidant activity. The results of extraction concentrated into crude extracts containing a mixture of chemical compounds that were produced by endophytic fungi and had different activities. The purification needed to get the desired active compound.

\section{Antioxidant activity test with DPPH method}

Endophytic fungi extract DMG1-DMG4 made in concentration series by diluting it in methanol. Each concentration series is then added with a DPPH solution. The antioxidant activity of a compound is determined by interpreting experimental data from the antioxidant test method. DPPH is a free radical that can react with compounds that can donate hydrogen atoms. The nature of DPPH is useful for testing the antioxidant activity of specific components in an extract. Because of the unpaired electrons, the DPPH gives a strong absorption at $517 \mathrm{~nm}$. When the electrons become paired up by the presence of free radical scavengers, the absorbance decreases stoichiometrically according to the number of electrons taken. The presence of antioxidant compounds can change the color of the DPPH solution from purple to yellow (Molyneux 2004; Bougatef et al. 2009). The DPPH react with UV light. Therefore, the test of antioxidant activity samples mixed with DPPH stored in a dark room.

The DPPH test was showed that DMG3 samples have high antioxidant activity with an $\mathrm{IC}_{50}$ value of $85.35 \mu \mathrm{g} / \mathrm{mL}$ and believed to be a strong antioxidant compared to other fungal extracts. The antioxidant activity of an extract can be categorized as strong $\left(\mathrm{IC}_{50}<200 \mu \mathrm{g} / \mathrm{mL}\right)$, moderate $\left(\mathrm{IC}_{50}\right.$ $200-1000 \mu \mathrm{g} / \mathrm{mL})$, and weak $\left(\mathrm{IC}_{50}>1000 \mu \mathrm{g} / \mathrm{mL}\right.$ ) (Molyneux 2004). The pure compound from endophytic fungi DMG3 is a inactivated antioxidants $\left(\mathrm{IC}_{50}>100\right.$ $\mu \mathrm{g} / \mathrm{mL})$.

It is often found that the antioxidant activity of an extract is more active compared to its pure compound which may be caused by a synergistic effect. If the antioxidant activity of an extract is stronger than the pure compound, in further research to find the source of antioxidant raw materials used in the form of extracts. 
Identification of endophytic fungi

The fungi of DMG3 which have antioxidant activity were identified. It was carried out using a phylogenetic analysis with 1000 times matching. Some DNA data on fungal species that sourced from NCBI compered with DNA data from DMG3 fungi. The phylogenetic method used to analyze the similarity of DNA. That is analysis represented as a branching system such as a tree diagram. That is known as a phylogenetic tree (Podani 2017). Phylogenetic trees are a diagram that shows kinship relations between organisms. Furthermore, determining the closeness of fungal DNA carried out by phylogenetic software. The phylogenetic tree of DMG3 is shown in Figure 2.

Phylogenetic tree of DMG3 was made by Mega software with the Neighbor-joining method. The phylogram topologies can indicate that the DMG3 is Cladosporium tenuissimum. It was located in the same clade location with $C$. tenuissimum strain APBSDSF6. That supported with high bootstrap (99\%). C. tenuissimum is mycoparasites which infects plants by forming rust on plant organs. Sharma and Heather (1978) reported that C. tenuissimum Cooke was a hyperparasite of rust in Melampsora larici-populin. Nasini et al. (2004) reported that $C$. tenuissimum was produced 5 Cladosporlos compounds. That is Urediniospores agents from $U$. appendiculatus as peanut rust agents. that's fungi produced compound had the potential to inhibit rust in germination. Fujii et al. (1995) succeeded in isolating the caladospolide compound from C. tenuissimum. Compounds isolated from C. tenuissimum are generally derivatives of lactone. This study was showed that $C$. tenuissimum produce secondary metabolites. Its biological activity is higher than the host. On this study revealed that $C$. tenuissimum associated in $S$. mahagoni were able to produce compounds ((5-hydroxy2H-piran 2oxo-4-yl) methyl acetate) (Compound 1). These compounds have not found in other Cladosporium sp.

Isolation and identification of pure compounds from the active ethyl acetate fraction of endophytic fungi extract

Compound 1 as a white crystal which has Rf value 0.46 with eluent $n$-hexane: ethyl acetate $(2: 8)$. It was analyzed by the spectroscopic method to determine the structure of the resulting compound. The UV spectrum of compound 1 has $\lambda \max 273 \mathrm{~nm}$. After the addition of $\mathrm{NaOH}$ a bathochromic shift occurs which produces $\lambda$ max $313 \mathrm{~nm}$. The results of the analysis with UV-Vis spectroscopy showed that compound 1 had free $\mathrm{OH}$ group. It showed the wavelength had a greater shift when it added with $\mathrm{NaOH}$ shear reagent. The IR spectrum $(\mathrm{KBr})$ of compound 1 indicates the presence of $\mathrm{OH}$ group at $3367.7 \mathrm{~cm}^{-1}$. $\mathrm{CH}$ aromatic at $3111.2 \mathrm{~cm}^{-1}$. CH-aliphatic at $2924.1 \mathrm{~cm}^{-1}$, COester stretches at $1730.2 \mathrm{~cm}^{-1}$ and $1662.6 \mathrm{~cm}^{-1}$ with a sharp pick. $\mathrm{C}=\mathrm{C}$ aromatic at $16269.9 \mathrm{~cm}^{-1}$ and $\mathrm{CO}$-ester bending at $1255.7 \mathrm{~cm}^{-1}$. The presence of CO-ester-stretching and warping indicates that compound 1 has a lactone ring which has a side chain CO-ester. The ${ }^{1} \mathrm{H}-\mathrm{NMR}$ spectrum showed (Fig 1) that compound 1 has four protons. Then have a chemical environment with a methyl group signals at $\delta_{\mathrm{H}} 2.16(3 \mathrm{H} ; \mathrm{s})$. The methylene signals at $\delta_{\mathrm{H}} 4.92(2 \mathrm{H} ; \mathrm{s})$, and two aromatic protons at $\delta_{\mathrm{H}} 6,50(\mathrm{H} ; \mathrm{s})$ and $\delta_{\mathrm{H}} 7.85(\mathrm{H}$; s).

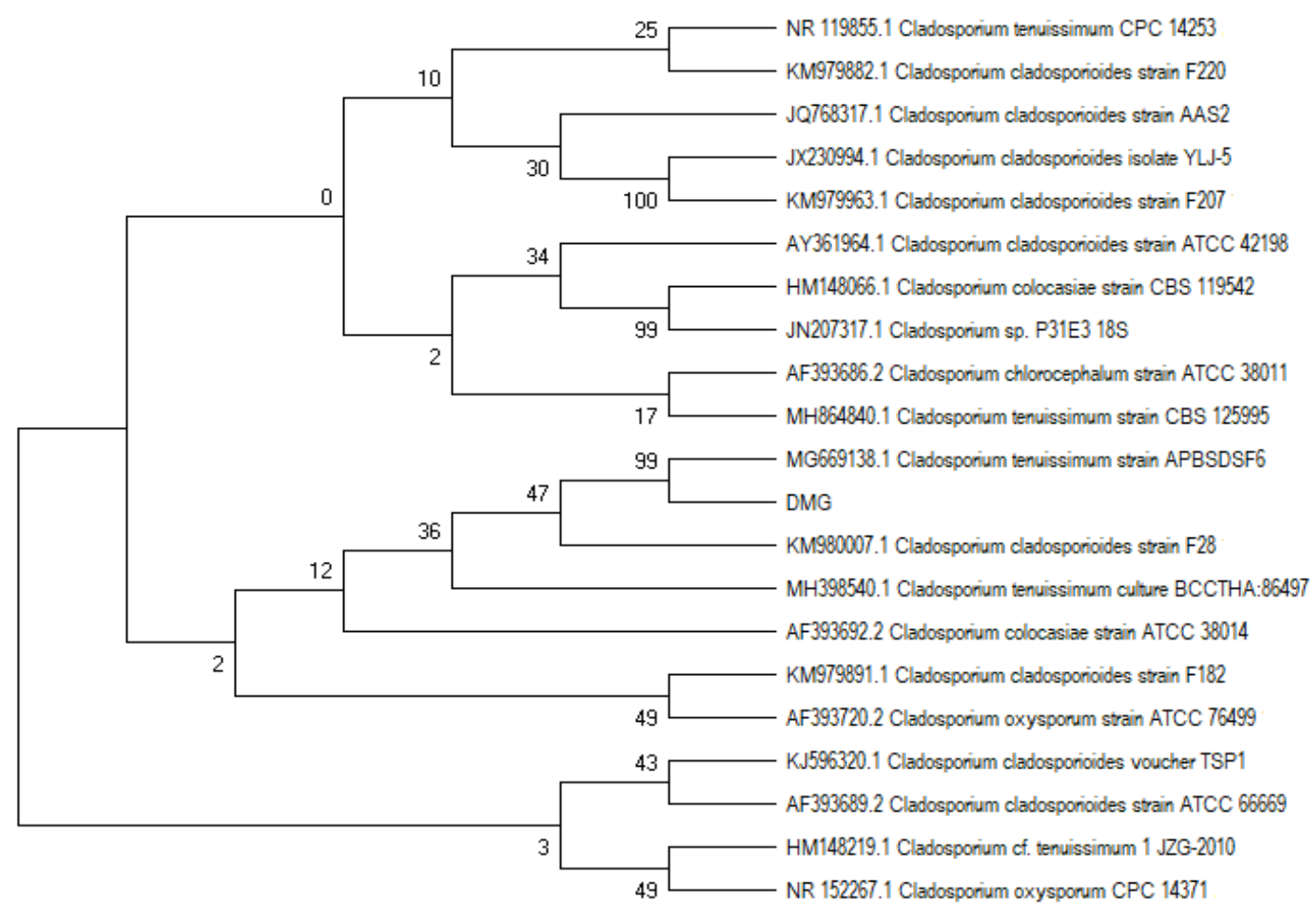

Figure 2. Phylogenetic trees of DMG3 
The ${ }^{13} \mathrm{C}$-NMR spectrum shows that compound 1 has 8 carbon chemical environments (Fig 1). The quaternary ester carbon on the lactone ring is at $\delta_{C} 174.0(\mathrm{C}-1)$. The quaternary carbon which binds the ester outside the lactone ring is at $\delta_{\mathrm{C}} 170.0(\mathrm{C}-7)$. The quaternary carbon bound to the $\mathrm{OH} \delta_{\mathrm{C}} 163.0(\mathrm{C}-4)$, carbon quaternary bound to the ester outside the lactone ring in $\delta_{C} 145.9$ (C-5). Methine carbon attached to the ring ester lactone at $\delta_{\mathrm{C}} 137.9(\mathrm{C}-5)$, carbon methine that in the lactone ring at $\delta_{\mathrm{C}} 111.2(\mathrm{C}-2)$. Carbon methylene outside the lactone ring at $\delta_{\mathrm{C}} 61.5(\mathrm{C}-6)$ and the methyl carbon at $\delta_{C} 20.7(\mathrm{C}-8)$. The HSQC and HMBC correlations shown in table 2, as compared with the data in the literature (Elfita et al. 2014). compound 1 is a 5hydroxy-2-oxo-2H-Piran-4-yl) methyl acetate.

\section{ACKNOWLEDGEMENTS}

The authors are grateful to Sriwijaya University for funding this research by Penelitian Unggulan Profesi 2019, with contract no. 0144.21/UN9/SB3.LP2M.PT/2019.

\section{REFERENCES}

Akharaiyi FC, Abiola MA. 2016. Isolation and cultivation of fungi with agrowastes formulated media. Der Pharma Chemica 8 (9): 56-62.

Altemimi A, Lakhssassi N, BAharlouei A, Watson DG, Lightfoot DA. 2017. Review. Phytochemicals: Extraction, isolation, and identification of bioactive compounds from plant extracts. Plants (Basel) 6 (4): E42. DOI: 10.3390/plants6040042.

Aguilar TAF, Navarro BCH, Perez JAM. 2016. Endogenous Antioxidants: A Review of Their Role in Oxidative Stress. Intech, London.

Bera TK, Chatterjee K, Ghosh D. 2015. In-vitro antioxidant properties of the hydro-methanol extract of the seeds of Swietenia mahagoni L Jacq. Biomark Genom Med 7 (1): 18-24.

Bougatef A, Muhammed H, Rafik B, Imen L, Yosra TE, Moncef N. 2009. Antioxidant and free radical-scavenging activities of smoothhound (Mustelus) muscle protein hydrolysates by gastrointestinal proteases. Food Chem 114 (4): 1198-1205.

Budiono B, Elfita E, Muharni M, Yohandini H, Widjajanti H. 2019. Antioxidant Activity of Syzygium samarangense L. and their endophytic fungi. Molekul 14 (1): 48-55.

Clifton EH, Jaroski ST, Coates BS, Hodgson EW, Gassmann AJ. 2018. Effects of endophytic entomopathogenic fungi on soybean aphid and identification of Metarhizium isolate from agricultural fields. PLoS ONE 13(3): e0194815. DOI: 10.1371/journal.pone.0194815.

Deepthi VC, Sumathi S, Faisal M, Elyas K. 2018. Isolation and identification of endophytic fungi with antimicrobial activities from the leaves of Elaeocarpus sphaericus (Gaertn.) K. Schum. and Myristica fragrants Houtt. Intl J Pharm Sci Res 9 (7): 2783-2791.

Dompeipen EJ, Srikandace Y, Suharso WP, Cahyana H, Simanjuntak P. 2011. Potential endophytic microbes selection for antidiabetic bioactive compounds production. Asian J Biochem 6 (6): 465-471.

Elfita, Munawar, Muharni, Sudrajar MA. 2014. Identification of new lactone derivatives isolated from Trichoderma $s p$., an endophytic fungus of brotowali (Tinospora crispa). Hayati J Biosci 21 (1): 15-20.

Elfita, Muharni, Munawar. 2015. Endophytic fungi isolated from sambiloto (Andrographis paniculata Nees) as a source of fungal lipid production. J Chem Pharm Res 7 (9S): 66-69.

Felsenstein J. 1989. PHYLIP-Phylogeny Inference Package (Version 3.2). Cladistics 5: 164-166.
Fouda AH, Hassan SE., Eid AM, Ewais EE. 2015. Biotechnological applications of fungal endophytes associated with medicinal plant Asclepias sinaica (Bioss.). Ann Agric Sci 60 (1): 95-104.

Fujii Y, Fukuda A, Hamasaki T, Ichimoto I, Nakajima H. 1995. Twelvemembered lactones produced by Cladosporium tenuissimum and the plant growth retardant activity of caladospolide B. Phytochemistry 40 (5): 1443-1446

Hannula SM, Veen JAV. 2016. Primer sets developed for functional genes reveal shifts in functionally of fungal community in soils. Front Microbiol 7: 1-13.

Hyde K, Soytong K. 2008.The fungal endophyte dilemma. Fungal Divers 33: $163-173$

Jalgaonwala, Ruby E, Mohite BV, Mahajan RT. 2011. A review: Natural products from plant-associated endophytic fungi. J Microbiol Biotechnol Res 1 (2): 21-32.

Kasote DM, Hegde MV, Katyare SS. 2013. Mitochondrial dysfunction in psychiatric 5 and neurological diseases: cause (s), consequence (s), and implications of antioxidant therapy. Biofactors 39 (4): 392-406.

Liang H, Xing Y, Chen J, Zhang D, Guo S, Wang C. 2012. Antimicrobial activities of endophytic fungi isolated from Ophiopogon japonicus (Liliaceae). BMC Compl Altern Med 12 (238): 2-6.

Ludwig-Muller J. 2015. Plant and endophytes: equal partners in secondary metabolite production?. Biotechnol Lett 37 (7): 1325-1334.

Nasini G, Arnone A, Assante G, Bava A, Moricca S, Ragazzi A. 2004. Secondary mould metabolites of Cladosporium tenuissimum, a hyperparasite of ruts fungi. Phytochemistry 65: 2107-2111.

Mishra VK, Passari AK, Chandra P, Leo VV, Kumar B, Uthandi S, Thankappan S, Gupta VK, Singh BP. 2017. Determination and production of antimicrobial compound by Aspergillus clavatonanicus strain MJ31, an endophytic fungus from Mirabilis jalapa L. using UPLC-ESI-MS/MS and TD-GC-MS analysis. PLoS ONE 12 (10): e0186234. DOI: 10.1371/journal.pone.0186234.

Muharni M, Fitrya F, Ruliza MO, Susanti DA, Elfita E. 2014. Di-(2ethylhexyl)phthalate and pyranone derivated from endophytic fungi Penicillium sp. the leave of Kunyit Putih (Curcuma zedoaria). Indon J Chem 14 (3): 290-296.

Mutmainnah. 2016. Sumber alternatif bahan baku obat diabetes mellitus dari fungi endofit tanaman mahoni (Swietenia mahagoni Jacq) dan uji aktivitas inhibitor $\alpha$-glukosidase. J Farmasi 4 (4): 153-158. [Indonesian]

Molyneux P. 2004. The use of the stable free radicals diphenylpicrylhydrazyl (DPPH for estimating antioxidant activity. Songklanakarin J Sci Technol 26 (2): 211-219.

Naveen YP, Rupini GD, Ahmed F, Urooj A. 2014. Pharmacological effects and active phytoconstituents of Swietenia mahagoni: A Review. J Integr Med 12 (2): 86-93.

Pansanit A, Pripdeevech P. 2018. Antibacterial secondary metabolites from an endophytic fungus, Arthrinium sp.MFLUCC16-1053 Isolated from Zingiber cassumunar. Mycology 9 (4): 264-272.

Pradeep FS, Begam MS, Palaniswamy M, Pradeep BV. 2013. Influence of culture media on growth and pigment production by Fusarium moniliforme KUMBF1201 isolated from paddy field soil. World Appl Sci J 22 (1): 70-77.

Podani J. 2017. Different from trees, more than metaphors: branching silhouettes-corals, cacti and the oaks. Syst Biol 66 (5): 737-753.

Puillandre N, Brisset J, Changnoux S, Cavillier E. 2017. TreePics: Visualizing trees with pictures. Eur J Taxon 353: 1-7.

Ramayulis R. 2015. Green Smoothie. PT Gramedia Pustaka Utama, Jakarta. [Indonesian]

Sharma JK, Heather WA. 1978. Parasitism of uredospores of Malampsora larici-populina Kleb. by Cladosporium sp. Eur J Plant Pathol 8 (1): 48-54.

Syahwiranto G, Theresih K. 2018. Isolasi senyawa metabolit sekunder dari biji mahoni (switenia mahagoni Jacq) metode ekstraksi soklet pelarut etanol. Jurnal Kimia Dasar 7 (4): 184-190. [Indonesian]

Yadav M, Yadaf A, Yadav JP. 2014. In vitro antioxidant activity and total phenolic content of endophytic fungi isolated from Eugenia jambolana Lam. Asian Pac J Trop Med 7: S256-S261. 